\title{
Identifying the Elements of Great Online Customer Encounters
}

\author{
Johanna Heinonen $^{1(\bowtie)}$ and Juho Pesonen ${ }^{2}$ \\ ${ }^{1}$ LAB University of Applied Sciences, Lappeenranta, Finland \\ Johanna.heinonen@lab. fi \\ ${ }^{2}$ University of Eastern Finland, Joensuu, Finland \\ juho.pesonen@uef.fi
}

\begin{abstract}
Customer service is a major factor in the success of digital marketing. This study examines the service encounters between tourists and service providers, in this case, Visit Helsinki. The goal is to understand what are the dimensions of service quality in online chat discussions between tourists and DMO personnel and what elements in these discussions support the co-creation of great customer experiences. Altogether 123 chat discussions in June 2020 were downloaded and analysed using qualitative content analysis and statistical tests. The results show that great customer experiences are the result of extensive effort from the customer service agents where they go beyond just providing a satisfactory solution for the customer. The results are managerially important for destinations and tourism businesses around the world and increase the theoretical understanding of the moment of truth concept and its different elements in online service encounters.
\end{abstract}

Keywords: Customer service $\cdot$ Online service $\cdot$ Customer satisfaction $\cdot$ Customer value $\cdot$ Chat service

\section{Introduction}

\subsection{Background}

One of the most critical elements in producing services is the customer encounter, a situation where the customer and the service provider meet each other [1]. This service encounter is increasingly happening online. Furthermore, the challenge is not only to provide high-quality services as such but also to communicate with customers in such a manner that the service exceeds their expectations. This does not only improve customer satisfaction but also helps the company to improve its processes more effectively, motivate its personnel and build the company image and reputation successfully [1]. When encountering a customer in an online medium, the company finds itself in a situation where the old face-to-face service procedures do not work anymore. Without gestures, mimes, and tone of voice, the written context becomes essential as well as the technical elements like speed and visual design [2].

The demand for online services has increased during the past years [3-6]. Already in 2015 fifty-seven per cent of customers preferred to contact companies online [7] and the number has not at least decreased. Customers are often found complaining about 
bad online service that is the result of, for example, unanswered questions [6], unpolite customer service agents [5], or unkept promises [6].

Research of online customer service has focused on technical issues, like information quality, website design, social media, and the role of chatbots or self-service [8], among others. Several researchers [e.g. 8, 9] have suggested more research on the moment of truths in technology-mediated encounters and thus improve the understanding of the critical elements in online customer service.

The purpose of this study is to increase understanding of the elements of great service in customer online service encounters. The study is inspired by Bitner and Wang [10], who encouraged researchers to study the prerequisites of good service in micro-level conversations in technology-mediated encounters. This study first identifies the elements of service quality in online chat discussions and then analyses how they support or undermine a great customer online service experience.

\section{Theoretical Framework}

\subsection{Customer Service Encounter}

Customer encounter can be considered as the core competence of a service business [11]. However, the concept of customer service is complex. Depending on the perspective and the author, it can be seen as a momentary interaction, as an offering - a package - of services, [12] or as a longer process [13] that is affected by actors not visible in the service event or outside of it, i.e. other customers and online reviews. Traditionally, service has taken place in direct customer encounters, usually in the faceto-face meetings between the customer and the service provider [14]. In a service encounter, a customer and a service provider interact and participate actively [12] in core service, i.e. in a moment of truth $[9,10]$, a unique situation, in which the perceptions of customers are tested.

Many companies have realized the meaning of service encounters online and invested in more effective customer-technology interactions in the moment of truth [8]. These interactions can happen in many channels. Customer's capabilities, the availability of technology and, also, the co-creative role customer plays, determines which channel the customer chooses. Today, service encounters can be divided into three different types: remote encounters, phone encounters, and face-to-face encounters [15]. ICT-mediated service encounters are part of the remote encounters.

Larivière et al. [16] talk about service encounter 2.0 which they define as follows: "any customer-company interaction that results from a service system that is comprised of interrelated technologies (either company-or customer-owned), human actors (employees and customers), physical/digital environments and company/customer processes." These service encounter $2.0 \mathrm{~s}$ are increasingly important in the tourism field and a much better understanding of these encounters is needed to provide customers with the service that they expect and that even might delight them. 


\subsection{Online Service Encounters and Service Quality}

Service quality depends on how customers' experiences are equivalent to customers' expectations, i.e. the customer is always the one who decides how the service experience was and this judgment can vary from one customer to another $[12,17]$ The main issue in producing high-quality services is to fulfil customers' expectations or even exceed them [15]. Service quality is traditionally defined through five variables: tangibles, reliability, responsiveness, assurance and empathy [17-19]. Tangibles include the place where service is produced, the equipment that is used as well as written materials. With reliability researchers refer to a company's capability to perform the service it promises to its customer's. Responsiveness means the company's ability to give customers the help they need to provide the demanded service. Assurance is an outcome of employees' professionalism, knowledge and polite behaviour as well as the way they create trust and confidence. Empathy includes listening and personal, tailormade attention to each separate customer [18].

These traditional elements are further defined and developed by Jawardheena [19], Ansari [20], Miceli [21], and Immonen [22] in the online setting. Most of these are adapted from the traditional model with specific emphasis on challenges caused by the technology environment. Quality elements in an online setting are called Effectiveness, Responsiveness, Politeness and Personalization by the researchers [19-22]. Effectiveness is defined as the ability to answer customer requests fast without delays. Also, if delays should appear, it is mentioned that customers should be informed of them and their length instantly. Responsiveness is characterized by solving customer problems and fulfilling customer expectations. Politeness refers to service providers professionalism, trustfulness and polite behaviour and can be analysed through thanking, apologising and way of greeting customers. With personalization, each customer gets tailor-made service, targeted especially to him to answer his questions and solve his problems [19-22]. Also, the length of the text, its structure and readability are important factors in online encounters [23], but precise effects of these on customer online experience in tourism are still largely unexplored.

Figure 1 builds upon the aforementioned literature to form a framework for analysing service quality elements. In addition to the traditional service quality elements, the online context adds several new perspectives that need to be accounted for.

Studies from online shopping have shown some central flaws in encounters causing dissatisfaction [24]. These are a failure in technology, failure in processes or failure in customer interaction. Also, slowness, easiness, competence and attitude were considered important factors. Customers wanted the service or the service agent to "get it done" while the service should be easy, effortless and enjoyable for the customer. This can be considered as part of the Responsiveness element.

Many authors [25-27] have stated that web 2.0 has not only a great effect on customer experience but also plays a major role in creating them. Thus digital service encounters should be taken into account during every step of the customer journey. Requirements for successful online presence during the customer journey lies in the understanding of the customer and his or her needs [28]. In all steps, it is important to activate the customer and create an interactive, collaborative and continual atmosphere online [29]. 


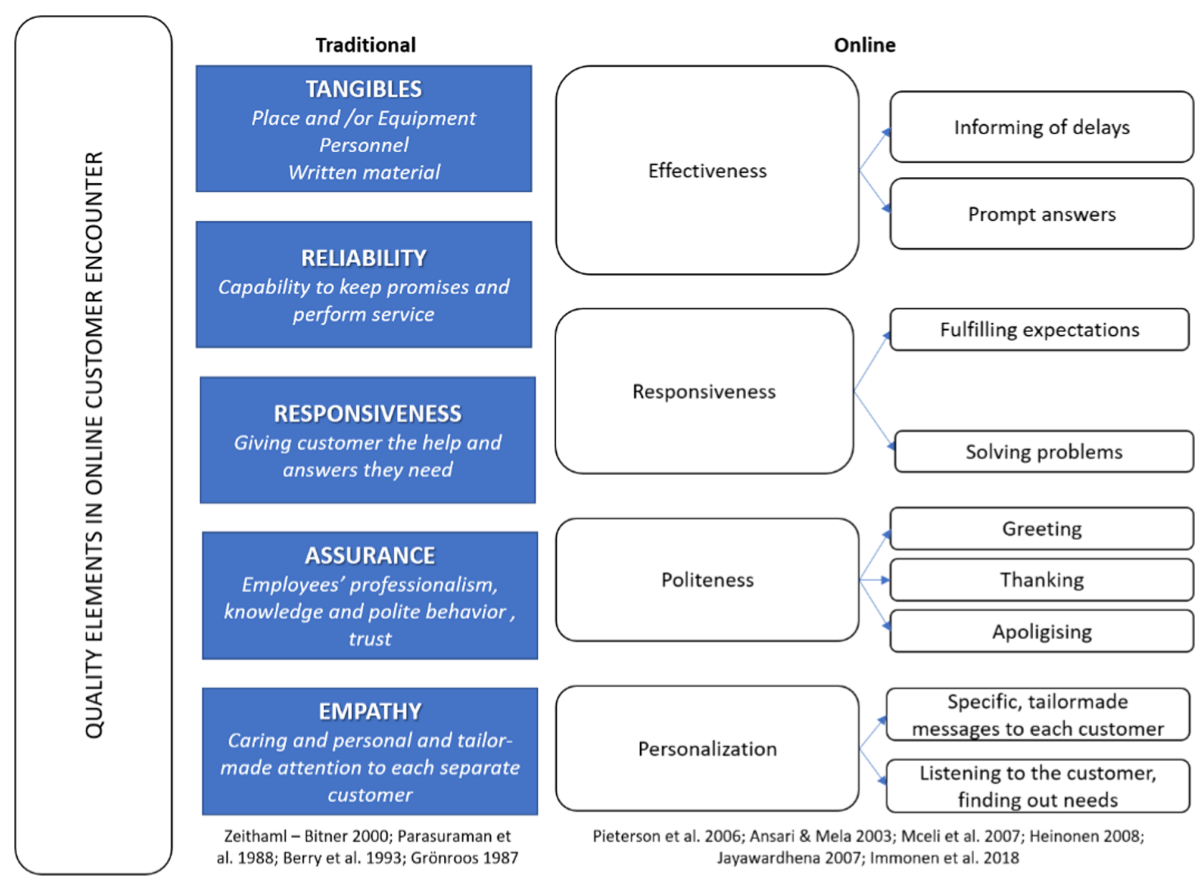

Fig. 1. The adapted framework of service quality elements

The service value, and thereby also the customer experience, has its grounds in either the tangible benefits customer experiences by participating in the service cocreation or the emotional benefits $[22,30]$. This is also supported by the concept of customer engagement, which describes customers mental state and conviction when she or he feels committed and safe in a co-creative customer relationship [29]. Thus an important element to study is also Customer responses.

\section{Research}

\subsection{Target Group and Data Collection}

In this study, the framework presented in Fig. 1 is used to study online customer encounters and improve our understanding of the online service quality elements. We focus on understanding how the service quality elements contribute to customer service that exceeds customer expectations. Distinguishing great service from satisfactory service provides an even deeper understanding of the customer encounters online.

Data for this study were collected during June 2020 among Visit Helsinki chat users. Visit Helsinki is one of the biggest DMOs (Destination Management Organisation) in Finland. Chat users included both Finnish (domestic) and foreign customers asking for information about services and attractions in Helsinki. Two service agents from Visit Helsinki responded to all these discussions. 
In total, data included 123 discussions that lasted $18 \mathrm{~min}$ on average and included 1623 lines in total (including both service agents' and customer's lines). Even though this might sound like a proper amount of data, it is still limited to the COVID-19 situation all over the world during summer 2020.

Data were analysed as anonymous with SPSS 27.0 and the focus was merely on the discussions and service quality elements in them. Due to the anonymity, it is assumed that all 123 discussions had a different, unique customer.

The main topics in these discussions involved different events in Helsinki (20 discussions), activities (18), opening hours (15) and opening hours (11 discussions). Surprisingly, there were also quite a many customers asking about jobs, entrepreneurship and co-operation in Helsinki (13 in total).

\subsection{Methodology}

The study can be described as abductive [31], since it starts with everyday observations and descriptions concerning online customer service, and then moves for deeper analysis and understanding of them based on literature. Content analysis was chosen as the research approach as it allows a holistic view and generalisation of the chat material, but at the same time, it provides a possibility for a deeper understanding of effects [32]. The cornerstone in content analysis is on messages. It provides an objective and systematic way to analyse material with preset, theory-based categories. Its nature is descriptive, not explanatory [32].

The analysis involved coding and categorizing the data first into four main service quality elements, based on the framework presented in Fig. 1: Effectiveness, Responsiveness, Politeness and Personalization. Each discussion was carefully read and each line from the text-based chat data was placed underneath a suitable category. Delays and lengths were calculated and the appearance of analysis elements was quantified as 0 (not existing) or 1 (existing).

For a deeper understanding, the service elements were divided into subcategories, with help of which the qualitative data was modified in a quantified form, which enables to better distinguish the connection between the elements and customer satisfaction.

Effectiveness included two sub-categories: length of delay in minutes and information on whether the customer was informed of the delays. Responsiveness refers to service agents' response and action, and whether the discussion fulfilled the expectations and solved the problems of the customer. Also, during the analysis of data, two extra subcategories for analysis of Responsiveness arose. These were "Giving alternatives and links" and "Providing the customer further contact information". Politeness was studied based on phrases the service agent used. Phrases like greeting and thanking and apologizing were interpreted as polite. Personalization was analysed based on whether the service agent asked further questions to find out the needs of a customer and whether he showed effort for fulfilling the needs.

Visit Helsinki did not have any satisfaction measurement system in place in their online chat. To define the outcomes of the customer discussions were analysed and 19 cases where the customer praised the encounter or the customer service agent at the end of the encounter (see Example 1) were identified These cases were coded as great 
customer service encounters and the differences between these and the other encounters were analysed using statistical methods (Table 1). Even though it is possible that in some additional cases customers experienced great service, the 19 cases selected surely belonged to that category as customers took additional actions to praise the service. The quantified topics in the discussions were based on the framework presented in Fig. 1.

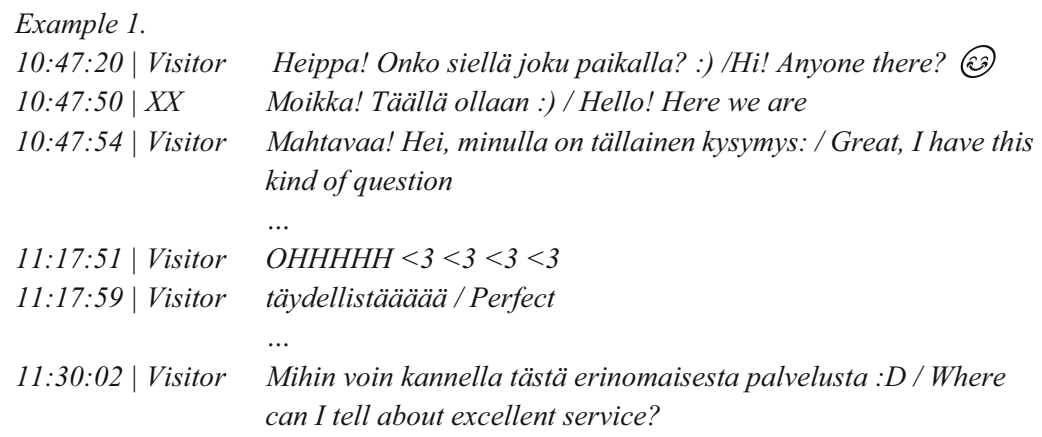

\subsection{Findings}

In total there were 123 discussions from 22 days in June 2020. The majority of the discussion was in Finnish (83) and the rest (41) in English. Most of the discussions concerned topics like events (20), opening hours (15), activities (18), cooperation with Visit Helsinki (10), attractions (11) and cooking places (7).

The first element of service quality (Table 1), Effectiveness, shows that in great service, the customer service agents (SA) kept the customer better on track about what is happening by informing them about delays and wait times. Delay times and lengths of discussions were longer in services resulting in a great service experience. It could be that long delays in a discussion can be alleviated by keeping the customer on track with what is happening. With longer delays, the discussions took longer in great online service encounters than in other discussions. In these great customer encounters the SAs used considerably much more lines than in other discussions, even though the customers messaged equally much in both cases.

Responsiveness analysed whether the customer's problem was solved and whether the customer expectations were fulfilled. Based on our analysis, 67\% (83) of discussions solved the problem and $28 \%$ (35) fulfilled expectations. All the customer encounters resulting in customers praising the service were coded as fulfilling expectations and solving problems, as these encounters probably even exceeded expectations.

When analysing Politeness, we can see that in great service encounters SAs greeted and thanked the customers more than in normal customers encounters. Also, SAs used more emoticons in encounters resulting in great experiences compared to normal encounters. 
Table 1. Comparing effects of service elements on great online customer service

\begin{tabular}{|c|c|c|c|}
\hline Variables & $\begin{array}{l}\text { Normal service } \\
(\mathrm{n}=104)\end{array}$ & $\begin{array}{l}\text { Great service } \\
(\mathrm{n}=19)\end{array}$ & $\begin{array}{l}\text { Statistically } \\
\text { significant difference }\end{array}$ \\
\hline \multicolumn{4}{|l|}{ Effectiveness } \\
\hline Informing of delays and waiting & & & $\begin{array}{l}X^{2}=12.03, \text { df }=2 \\
p=0.002\end{array}$ \\
\hline 0 times & $51.9 \%$ & $36.8 \%$ & \\
\hline 1 time & $44.2 \%$ & $36.8 \%$ & \\
\hline 2 or 3 times & $3.8 \%$ & $26.3 \%$ & \\
\hline \multicolumn{4}{|l|}{ Prompt answers } \\
\hline Delay in minutes & $\begin{array}{l}8.2 \min \\
(\mathrm{SD}=6.8)\end{array}$ & $\begin{array}{l}14.7 \text { min } \\
(\mathrm{SD}=10.4)\end{array}$ & $\begin{array}{l}\text { Mann-Whiteny U-test } \\
p=0.003\end{array}$ \\
\hline Length of discussion in minutes & $\begin{array}{l}20.0 \mathrm{~min} \\
(\mathrm{SD}=21.7)\end{array}$ & $\begin{array}{l}27.1 \mathrm{~min} \\
(\mathrm{SD}=16.0)\end{array}$ & $\begin{array}{l}\text { Mann-Whiteny U-test } \\
p=0.013\end{array}$ \\
\hline $\begin{array}{l}\text { Number of SA lines in the } \\
\text { discussion (mean) }\end{array}$ & $6.9(\mathrm{SD}=3.6)$ & $\begin{array}{l}16.0 \\
(\mathrm{SD}=11.0)\end{array}$ & $\begin{array}{l}\text { Mann-Whiteny U-test } \\
\mathrm{p}<0.001\end{array}$ \\
\hline $\begin{array}{l}\text { Number of customer lines in the } \\
\text { discussion (mean) }\end{array}$ & $4.9(\mathrm{SD}=5.5)$ & $5.0(3.2)$ & n.s. \\
\hline \multicolumn{4}{|l|}{ Responsiveness } \\
\hline Fulfilling expectations & $15.4 \%$ & $100 \%$ & \\
\hline Solving problems & $61.2 \%$ & $100 \%$ & \\
\hline $\begin{array}{l}\text { Customers repeating themselves in } \\
\text { discussion }\end{array}$ & $4.8 \%$ & $0 \%$ & n.s. \\
\hline \multicolumn{4}{|l|}{ Politeness } \\
\hline SA greeting the customer & & & $\begin{array}{l}X^{2}=9.44, d f=2 \\
p=0.009\end{array}$ \\
\hline 1 time & $19.2 \%$ & $5.3 \%$ & \\
\hline 2 times & $49.0 \%$ & $26.3 \%$ & \\
\hline 3 or 4 times & $31.7 \%$ & $68.4 \%$ & \\
\hline SA thanking the customer & & & $\begin{array}{l}X^{2}=10.45, d f=2 \\
p=0.005\end{array}$ \\
\hline 0 times & $46.2 \%$ & $21.1 \%$ & \\
\hline 1 time & $46.2 \%$ & $47.4 \%$ & \\
\hline 2 times & $7.7 \%$ & $31.6 \%$ & \\
\hline SA apologising from the customer & & & n.s. \\
\hline 0 times & $93.3 \%$ & $94.7 \%$ & \\
\hline 1 time & $4.8 \%$ & $5.3 \%$ & \\
\hline 2 or 3 times & $2.0 \%$ & $0 \%$ & \\
\hline $\begin{array}{l}\text { Number of emoticons used by the } \\
\text { customer (mean) }\end{array}$ & $1.6(\mathrm{SD}=0.8)$ & $1.9(\mathrm{SD}=1.3)$ & n.s. \\
\hline $\begin{array}{l}\text { Number of emoticons used by the } \\
\text { SA (mean) }\end{array}$ & $1.6(\mathrm{SD}=0.8)$ & $3.7(\mathrm{SD}=2.4)$ & $\begin{array}{l}\text { Mann-Whiteny U-test } \\
\mathrm{p}=0.015\end{array}$ \\
\hline
\end{tabular}


Table 1. (continued)

\begin{tabular}{l|l|l|l}
\hline Variables & $\begin{array}{l}\text { Normal service } \\
(\mathrm{n}=104)\end{array}$ & $\begin{array}{l}\text { Great service } \\
(\mathrm{n}=19)\end{array}$ & $\begin{array}{l}\text { Statistically } \\
\text { significant difference }\end{array}$ \\
\hline Personalization & & $57.9 \%$ & $\begin{array}{l}\text { Fisher's Exact Test } \\
\mathrm{p}<0.001\end{array}$ \\
\hline SA asking for further information & $22.1 \%$ & $52.6 \%$ & $\begin{array}{l}\text { Fisher's Exact Test } \\
\mathrm{p}<0.001\end{array}$ \\
\hline $\begin{array}{l}\text { SA giving an effort for finding the } \\
\text { best solution }\end{array}$ & $11.5 \%$ & $3.3(\mathrm{SD}=2.6)$ & $\begin{array}{l}\text { Mann-Whiteny U-test } \\
\mathrm{p}<0.001\end{array}$ \\
\hline \begin{tabular}{l} 
Links per discussion in average \\
\hline
\end{tabular} & $1.2(\mathrm{SD}=1.2)$ & &
\end{tabular}

In Personalization, the results show that the efforts SAs put into the service encounter matters significantly. The more information they find and the better the solution solves the customer problems, the more likely it is that the customer encounter is great from the customer perspective.

\section{Discussion and Conclusions}

The purpose of the research was to find out how service quality elements are represented in online chat discussions and how they support achieving a great service experience. A framework for elements was created based on the literature [17-22] and divided into four main elements: Responsiveness, Effectiveness, Politeness and Personalization. The framework was partially adapted from the traditional service quality literature. In the data analysis, some elements were added and also customer response part was included. The four elements with added customer response information are suitable to analyze online discussions. Naturally, the online environment adds specific elements like emoticons and sending links to the service encounters, which were also included in this study.

Based on the data, we can see great customer service online is provided with the same elements as it is in a live situation. Solving the customer's problem and even exceeding his expectations is the key in an online chat environment [6]. While lacking mimes, tone of voice and gestures of face-to-face encounters, online customer encounters have other ways to create great service experiences.

It is important to inform them about changes and what is happening. This concerns as well the delays as the change of service agent. The findings of this study are in accordance with Meuter et al. [33] and van Dolen et al. [34] and indicate dissatisfaction among customers when delays were long without any notice. It might also indicate distrust when a customer is facing a new person without warning. The results show that taking a long time to answer questions does reduce the quality of online service if the customer is updated with what is happening and gets the information they seek in the end. This is also supported by Jayawardhena [19] and even mentioned in the traditional framework [17]. When customers do not see what is happening on the other side very few customers wait or respond to the delayed answers, which can be considered as a sign of unsatisfaction [6]. 
Also, the style of communication was important in data. Personalized, polite and trustful experiences do not include mass messages. Thanking the customer is essential.

Based on these elements, we can provide an answer for Bitner and Wang's question "What precisely is good service in micro-level conversations in technology-mediated encounters?" It is caring about the customer and showing him that with elements from politeness like thanking, greeting, using emoticons and asking questions. Great customer service is also created when the service agent invests in the customer and goes to great lengths to solve his problem. This does not happen by merely posting links or giving telephone numbers and email addresses, it requires more personal touch and more extensive communication of information.

To conclude, service quality is always the customer's subjective experience. To provide superior service, a company must think and act from the customer perspective [7]. However, experiential customer service needs still some sharpening. From the destination marketing point of view, this is most likely something in common for many destinations. Great customer service needs resources to allow customer service agents to spend enough time to craft detailed, personalized and effective communication. It is possible to solve customer problems with fewer resources, but great service encounters typically need more time and effort. This is also the managerial implication of this paper.

Since the literature on online customer service quality and experiences in service encounters is more concentrated on technical and structural elements of service, this study elaborates on the complexity of achieving a competitive advantage in online customer service. It also tests the elements from the literature and brings some deeper understanding to them. The results demonstrate that many caveats can result in nonsatisfied customers. Satisfaction can be considered as the minimum level to achieve and to build upon. The next step would be to create unique, experiential customer service to gain a competitive advantage, i.e. to have great customer service. However, more research on this topic is needed.

Figure 1 demonstrates that experiential aspects of online customer service are still missing from the literature. The findings of this study demonstrate that tourism organizations can have difficulties in reaching satisfactory customer service levels. As a result, cases, where online customer services can be considered experiential, are difficult to find and analyse. For further studies, it is important to deepen the research to the emotional state and thus analyse the discussions with the emotional and sentimental elements. It is also worth studying the customer point of view to ensure the proper interpretations.

\section{References}

1. 2021 Customer Expectations Report: What Customers Expect From a Modern Online Shopping Experience. Gladly. https://www.gladly.com/reports/2021-customer-expectationsreport/. Accessed 15 Oct 2021

2. Lennon R, Harris J (2002) Customer service on the web: a cross-industry investigation. J Target Meas Anal Market 10(4):325-338 
3. Januszewska M, Jaremen DE, Nawrocka E (2015) The effects of the use of ICT by tourism enterprises. Serv Manag 2(16):65-73

4. Ficarelli S, Sendra S, Ferrando L, Lloret J (2013) Effects of web technologies on tourism industry in some southern European countries. In: quaestus multidisciplinary research journal. Proceedings of WEB 2013: the first international conference on building and exploring web based environments, pp 49-56

5. Sehgal H Customer Experience Statistics Which Will Impact Your Business in 2016. https:// www.ameyo.com/blog/customer-experience-statistics-which-will-impact-your-business-in2016. Accessed 18 Oct 2021

6. 2020 CGS Customer Services Preferences in Times of Distress Survey. https://www.cgsinc. com/en/resources/customer-service-in-crisis. Accessed 18 Oct 2021

7. Customer Service Stats for 2020. https://www.customerthermometer.com/customer-service/ customer-service-and-satisfaction-statistics-for-2020/. Accessed 18 Oct 2021

8. Buhalis D (2019) Technology in tourism-from information communication technologies to eTourism and smart tourism towards ambient intelligence tourism: a perspective article. Tour Rev 75(1), 267-272

9. Voorhees CM et al (2017) Service encounters, experiences and the customer journey: defining the field and a call to expand our lens. J Bus Res 79:269-280

10. Bitner MJ, Wang HS (2014) Service encounters in service marketing research. In: Rust RT, Huang M-H (eds) Handbook of service marketing research. Edward Elgar Publishing Limited: Massachusettes

11. Carson D, Cromie S, McGowan P, Hill J (1995) Marketing and entrepreneurship in SMEs: an innovative approach. Prentice-Hall International, Great Britain

12. Grönroos C (2000) Creating a relationship dialogue: communication, interaction and value. The Market Rev No 1:5-14

13. Surprenant CF, Solomon MR (1987) Predictability and Personalization in the Service Encounter. J Market 51(2):86-96

14. Normann R (1991) Service management strategy and leadership in service businesses, 2nd edn. John Wiley and Sons, Chichester

15. Zeithaml V, Bitner J, Gremler DD (2013) Services marketing: integrating customer focus across the firm. McGraw-Hill, New York. 6th ed. -Item scale for measuring consumer perceptions of service quality. Journal of Retailing. 64, Spring, pp 12-40

16. Larivière B et al (2017) Service encounter 2.0: an investigation into the roles of technology, employees and customers. J Bus Res 79:238-246

17. Parasuraman A, Zeithaml V, Berry LL (1988) SERVQUAL: a multiple-item scale for measuring consumer perceptions of service quality. J Retail 64(1), 12-40. Spring

18. Berry L, Parasuraman A, Zeithaml VA (2002) Ten lessons for improving service quality. marketing science institute's working paper series, Report 93-107. In: Witkowski TH, Wolfinbarger MF. (eds.) Comparative service quality, German and American ratings across service settings, Journal of Business Research 55, pp 875-881

19. Jayawardhena $C$ (2007) Outcomes of service encounter quality in a business-to-business context. Ind Mark Manage 36(5):575-588

20. Ansari A, Mela CF (2003) E-customization. J Mark Res 40:131-145

21. Miceli G, Ricotta F, Costabile M (2007) Customizing customization: a conceptual framework for interactive personalization. J Inter Market 21(2):6-25

22. Immonen M, Sintonen S, Koivuniemi J (2018) The value of human interaction in service channels. Comput Hum Behav 78(2018):316-325

23. Mihalcescu C, Sion B, Marginean A (2016) The development, success and impact of electronic tourism in the digital age. J Inf Syst Operat Manag Bucharest 10(2), 416-424 
24. Ranaweera C (2005) A model of online customer behavior during the initial transaction: moderating effects of customer characteristics. Mark Theory 5(1):51-74

25. Mihajlović I (2014) ICT and new trends in consumer behaviour - new experiential knowledge. Opportunities or challenges for intermediaries. J Market Manag 2(1):43-46

26. Buhalis D, Law R (2008) Progress in information technology and tourism management: 20 years on and 10 years after the Internet-The state of eTourism research. Tour Manage 29 (4):609-623

27. Neuhofer B, Buhalis D, Ladkin A (2014) A typology of technologyenhanced tourism experiences. Int J Tour Res 16:340-350

28. Cohen AS, Prayag G, Moital M (2014) Consumer behaviour in tourism: concepts, influences and opportunities. Curr Issue Tour 17(10):872-909

29. Ge J (2014) Tourism marketing communications on a chinese social media platform. In: eProceedings of the ENTER $2014 \mathrm{PhD}$ workshop - information and communication technologies in tourism 2014, pp 11-19

30. Collier JE, Barnes DC (2015) Self-service delight: exploring the hedonic aspects of selfservice. J Bus Res 68(5):986-993

31. Kovalainen A, Eriksson P (2015) Qualitative methods in business research. Sage, A Practical Guide to Social Research

32. Neuendorf KA (2004) Content analysis: a contrast and complement to discourse analysis. Qual Methods Spring 2004:33-36

33. Meuter ML, Ostrom AL, Roundtree RI, Bitner MJ (2000) Self-service technologies: understanding customer satisfaction with technology-based service encounters. J Mark 64 (3):50-64

34. van Dolen W, de Ruyter K (2002) Moderated group chat: an empirical assessment of a new e-service encounter. Int J Serv Ind Manag 13(5):496-511

Open Access This chapter is licensed under the terms of the Creative Commons Attribution 4.0 International License (http://creativecommons.org/licenses/by/4.0/), which permits use, sharing, adaptation, distribution and reproduction in any medium or format, as long as you give appropriate credit to the original author(s) and the source, provide a link to the Creative Commons license and indicate if changes were made.

The images or other third party material in this chapter are included in the chapter's Creative Commons license, unless indicated otherwise in a credit line to the material. If material is not included in the chapter's Creative Commons license and your intended use is not permitted by statutory regulation or exceeds the permitted use, you will need to obtain permission directly from the copyright holder.

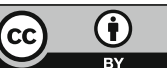

